\title{
HORRORY TEUMACZENIOWE CZY TŁUMACZE Z PIEKŁA RODEM? CZYLI KILKA SŁÓW O EFEKTYWNOŚCI KOMUNIKACJI INTERLINGWALNEJ
}

\author{
ALEKSANDRA MATULEWSKA
}

\section{Wprowadzenie}

Niniejsza praca ma na celu przedstawienie problemu efektywności komunikacji w świetle błędu dyskwalifikującego przekład nazywanego również błędem krytycznym (ang. fatal error) (Biel 2012, Dybiec-Gajer 2013) lub kardynalnym (Hejwowski 2004) w tekstach specjalistycznych. Najpierw zostanie przedstawiony krótki przegląd typologii błędów przekładowych. Następnie w zarysie zostanie omówiona efektywności komunikacji językowej. Na koniec zostaną przedstawione przykłady błędów krytycznych w oparciu o klasyfikację Hejwowskiego (2004). Praca została oparta na analizie literatury przedmiotu.

\section{Efektywność komunikacji znakowej}

Aby móc mówić o efektywności komunikacji trzeba sobie uświadomić, że

„efektywność komunikacji znakowej można rozumieć jako zgodność zamierzenia nadawcy znaku z treścią zrekonstruowaną przez odbiorcę" (Bańczerowski, Pogonowski, Zgółka 1982: 38).

Należy mieć świadomość, że znaki to zjawiska o charakterze kulturowym. Są one przejawem konwencji kulturowych i dlatego by móc je właściwie rozu- 
mieć i interpretować konieczna jest kompetencja kulturowa, która zdobywamy w ramach określonej wspólnoty komunikatywnej. Tłumacz jako specjalista w komunikacji międzyjęzykowej i międzykulturowej musi posiadać kompetencję kulturową zarówno w odniesieniu do wspólnoty komunikatywnej posługującej się językiem źródłowym jak i docelowym. Kompetencja kulturowa jest tutaj rozumiana jako swego rodzaju konglomerat złożony z kompetencji językowej, semiotycznej, komunikacyjnej, itd.

W pracach językoznawczych zwraca się uwagę na fakt, że kompetencja może być społeczna bądź indywidualistyczna. Inaczej mówiąc pewne komunikaty są zrozumiałe dla danej grupy społecznej, a inne tylko dla określonej jednostki. Efektywność indywidualistyczna nazywana też pragmatyczna:

\begin{abstract}
„Zostaje osiągnięta wówczas, gdy czynność komunikacyjna podjęta jest w oparciu o kompetencję określonego typu. Jednocześnie zaś sens komunikacyjny zamierzony przez nadawcę (rozumianego jako konkretna jednostka) jest dokładnie identyczny z sensem przypisywanym owej czynności przez odbiorcę (również konkretną jednostkę)." (Bańczerowski, Pogonowski, Zgółka 1982: 38-39).
\end{abstract}

Z kolei, efektywność społeczna dotyczy określonej grupy nadawców i odbiorców komunikatów i zależy ona:

„wyłącznie od skonwencjonalizowanych reguł kulturowych, czyli od kompetencji, np. językowej. (...) czynności komunikacyjne, w szczególności więc znaki, mają charakter czynności społecznych w tym sensie, że rezultaty realizowane poprzez podejmowanie tych czynności podlegają regulacji społecznej w oparciu o reguły społecznie obowiązujące, o świadomość społeczną. Chodzi o to, że podjęciu czynności znakowej towarzyszy (1) sens subiektywnie zamierzony przez podmiot tej czynności (nadawcę) oraz (2) rezultat społeczno-obiektywny przypisywany owej czynności w oparciu o reguły obowiązujące na gruncie określonej świadomości społecznej. Sens subiektywny zamierzony nie musi być oczywiście identyczny z rezultatem społeczno-obiektywnym" (Bańczerowski, Pogonowski, Zgółka 1982: 39).

Zgodnie z teorią wspólnot komunikatywnych L. Zabrockiego (1963) właściwe rozumienie komunikatu, zależy od naszej przynależności do określonej wspólnoty, która posługuje się językiem dostosowanym do własnych potrzeb komunikacyjnych. A zatem podstawową przesłanką efektywnej komunikacji znakowej jest po pierwsze posiadanie kompetencji wystarczających do właściwego zrozumienia komunikatu nadawanego przez nadawcę, a po drugie posiadanie kompetencji umożliwiających właściwą reakcję na taki komunikat np. nadanie odpowiedzi, zrozumiałej dla odbiorcy, a zarazem przynależność do określonej wspólnoty językowej ${ }^{1}$.

\footnotetext{
${ }^{1}$ „Efektywność komunikacji znakowej polega na zgodności zamierzenia subiektywnego nadawcy z rezultatem społeczno-obiektywnym przypisywanym danej, podjętej przez nadawcę czyn-
} 
Aby móc mówić o efektywności interlingwalnej komunikacji znakowej, najpierw muszą być zagwarantowane prawa do języka, w tym prawo do pomocy kompetentnego tłumacza w procesie komunikacji jeżeli uczestnicy procesu komunikacji nie znają w wystarczającym stopniu języków jakimi się posługują.

$\mathrm{Z}$ tego też względu należy sobie uświadomić, że wprawdzie $\mathrm{w}$ wielu krajach prawo do tłumacza jest zagwarantowane przepisami, ale w wielu miejscach na świecie problem ten nie jest do końca rozwiązany w sposób satysfakcjonujący dla uczestników komunikacji prawnej i prawniczej. Jednym z najczęściej przytaczanych przykładów w tym zakresie jest sprawa Negrón v. State of New York [1970], w której oskarżony i skazany na 20 lat więzienia za zabójstwo Negrón nie mógł nawet porozumieć się z reprezentującym go adwokatem z urzędu, który nie znał języka hiszpańskiego jakim władał oskarżony. Oskarżony miał możliwość zapoznania się z pewnymi kwestiami dotyczącymi swojego życia tylko podczas nielicznych momentów, gdy oskarżenie zatrudniało tłumacza ustnego, który streszczał mu fragmenty procesu. Tłumaczenie podczas tego procesu zachodziło zazwyczaj tylko w jednym kierunku z hiszpańskiego na angielski.

Sytuacja zmieniła się od tego czasu znacząco. Jednak nadal nie brakuje doniesień o nieprawidłowościach $w$ tym zakresie. Coraz rzadziej mamy do czynienia z sytuacją, w której nie zostaje powołany tłumacz. Niestety, często kwalifikacje tłumacza i jakość tłumaczenia pozostawiają wiele do życzenia. O takich sytuacjach coraz częściej opinię publiczną informuje prasa.

Dopiero gdy uczestnicy procesu komunikacji interlingwalnej mają zapewnione prawo do tłumacza można zacząć zajmować się kompetencjami tłumacza i problemami jakie w procesie przekładu się pojawiają.

W przekładoznawstwie poświęcono dużo uwagi kompetencjom tłumacza. Prace poświęcone kwalifikacjom, wykształceniu, intuicji wyrosły w dużej mierze z refleksji na temat trudności z jakimi borykają się tłumacze jak i świadomości jak często niedoskonałe są przekłady.Obok prac poświęconych kompetencjom tłumaczeniowym w XX wieku zaczęły powstawać prace z zakresu krytyki przekładu, w których koncentrowano się na analizie błędów w tekstach paralelnych (rozumianych jako tekst i jego przekład).

\section{Klasyfikacje błędów tłumaczeniowych}

W tej części pracy zostaną przedstawione klasyfikacje błędów w porządku chronologicznym, a szczególny nacisk zostanie położony na polską myśl translatoryczną. Jednym z pierwszych polskich badaczy, który zajął się problemami

ności, na gruncie określonej kompetencji stanowiącej fragment świadomości społecznej” (Bańczerowski, Pogonowski, Zgółka 1982: 39). 
tłumaczeniowymi i nazwał lapsologią dziedzinę wiedzy nimi się zajmującą jest F. Grucza (1978: 13), który wyróżnia dwa zasadnicze kategorie błędów:

1) błędy sensu stricto, które wynikają z nieopanowania lub niedostatecznego opanowania danego języka, czyli z niekompetencji i braku wiedzy tłumacza oraz

2) błędy sensu largo, które wynikają z innych czynników i są popełniane przez kompetentnych użytkowników danego języka, którzy zasadniczo potrafią skorygować takie błędy.

Jako ich przyczynę podaje zjawisko interferencji, które definiuje w następujący sposób:

„Tam, gdzie między uprzednio zinternalizowanym materiałem językowym a materiałem przyswajanym aktualnie zachodzi identyczność strukturalna, będziemy mieli do czynienia z tzw. transferem pozytywnym, natomiast tam, gdzie zachodzi odmienność strukturalna, może wystąpić zjawisko tzw. transferu negatywnego, który w lingwistyce i glottodydaktyce nazywa się zwykle interferencją. Interferencja jest więc zjawiskiem niepożądanym, prowadzi bowiem do tworzenia błędnych struktur i błędnych realizacji”. (Grucza, 1978: 17).

Należy pamiętać, że w niektórych językach używa się różnych terminów na oznaczenie takich błędów (ang. errors i mistakes, fr. erreurs i fautes.). Według M. Szczygłowskiej (2011: 400) w świetle antropocentrycznej teorii rzeczywistych języków ludzkich oraz teorii poznania u Gruczy

„błąd tłumaczeniowy pojmowany jest jako niewłaściwa rekonstrukcja informacji prymarnej wyrażonej przez tekst wyjściowy, w wyniku czego informacja prymarna oraz informacja docelowa są względem siebie heterogeniczne".

Inna polska badaczka zajmująca się przekładem tekstów nieliterackich, H. Dzierżanowska (1990), wyróżnia:

1) błędy ortograficzne (w zakresie pisowni i interpunkcji), które jak dosadnie ujmuje to autorka $\mathrm{w}$ dużej mierze wynikają $\mathrm{z}$ niedostatków w wykształceniu tłumacza, nadmiernej wiarze w własne siły nazywanej wręcz „zadufaniem we własną wiedzę" a także niesumiennym czy wręcz niechlujnym wykonaniu przekładu,

2) błędy gramatyczne (powstałe w formach morfologicznych, w elementach struktury grupy wyrazowej, w elementach struktury zdania),

3) błędy szyku wyrazów (w zdaniu i w grupie wyrazowej),

4) błędy leksykalne (wynikające z (i) niezgodności leksykalnej wyrazów np. zjawiska homonimii, (ii) różnic terminologicznych np. zjawiska polisemii i braku izomorfizmu terminologicznego $\mathrm{w}$ ramach określonych par językowych, (iii) niezgodności leksykalnej grup wyrazowych, czyli kolokacji),

5) błędy dotyczące adekwatności sytuacyjnej, stylistycznej, semantycznej. 
Błędy gramatyczne i szyku wyrazów oraz leksykalne zazwyczaj wynikają $\mathrm{z}$ interferencji wewnętrznej i zewnętrznej. $Z$ kolei błędy dotyczące adekwatności sytuacyjnej powstają

„gdy tłumacz kieruje się wyłącznie zasadami gramatyki formalnej, nie biorąc pod uwagę aspektów wynikających z kontekstu czyli gramatyki sytuacyjnej" (Dzierżanowska 1990: 97).

Błędy adekwatności stylistycznej obserwujemy natomiast

„gdy w przetłumaczonym tekście występują cechy specyficzne dla stylu języka oryginału, a obce dla języka przekładu. (...) Jednolitość stylu jest bardzo ważną zasadą w tłumaczeniu. Tekst pisany mieszaniną stylów czyta się źle" (Dzierżanowska 1990: 100).

Błędy adekwatności semantycznej przejawiają się opuszczeniem i dodaniem informacji.

W latach 90. XX wieku ukazała się pionierska praca przedstawiająca przegląd współczesnej myśli przekładoznawczej autorstwa A. Pisarskiej i T. Tomaszkiewicz, w której także przedstawiono problem błędów przekładowych. Autorki (1996: 144) uważają, że najogólniej błędy można podzielić na: błędy językowe i tłumaczeniowe. Te pierwsze wynikają bądź z interferencji zewnętrznej bądź braku wystarczających kompetencji tłumacza w zakresie języka docelowego. Ten drugi typ z kolei

,wynika z kilku przesłanek: ze zbyt bliskich kontaktów między językami, kiedy to formy języka źródłowego wpływają na formę przyjętą w języku docelowym, z nie zrozumienia tekstu oryginału przez thumacza, z nieprzystawania tekstu przekładu do tekstu oryginału, w którym albo zatracono pewne informacje istotne, albo dodano jakieś informacje, albo w interpretacji zbyt oddalono się od intencji oryginału" (Pisarska, Tomaszkiewicz 1996: 144).

Tak więc źródłem ich powstania są zasadniczo braki w zakresie kompetencji translacyjnych, a także wiedzy językowej i fachowej.

W pracy, która ukazała się również w 1996 roku Ch. Grabau zwraca uwagę na problem jakości przekładu w komunikacji prawniczej i wskazuje, że uczestnicy postępowania mający wpływ na nie (tzn. sędziowie) powinni być świadomi jakie typy błędów tłumaczeniowych mogą się pojawić. Wymienia tu następujące błędy:

1) przypisanie wypowiadanych słów osobie, która nie uczestniczyła w rozmowie,

2) błędy tłumaczeniowe polegające na niepoprawnym przekazaniu znaczenia komunikatu,

3) błędy dekodowania popełniane, gdy tłumacz niewłaściwie interpretuje komunikat w wyniku nieprawidłowego jego odkodowania 
Na temat podobnych problemów w przekładzie prawniczym pisała także polska badaczka B. Z. Kielar, koncentrując się jednak na konkretnych przykładach błędów i ich konsekwencjach komunikacyjnych (Kielar 1996, Kielar i Lewandowska 1999), a nie na ich systematycznej klasyfikacji.

Prac dotyczących błędów translacyjnych nie brak także w badaniach uczonych wyrosłych ze szkoły lipskiej. Niemiecka badaczka Ch. Nord (1999 za Kubacki 2014) zwraca uwagę na następujące typy błędów tłumaczeniowych:

1) pragmatyczne błędy tłumaczeniowe (dotyczące treści, sensu i specyficznych potrzeb odbiorcy),

2) kulturowe błędy tłumaczeniowe (dotyczące norm i konwencji obowiązujących w zakresie tworzenia danego gatunku tekstów),

3) formalne błędy tłumaczeniowe (dotyczące aspektów formalnych takich jak np. typografia tekstu) (za Kubacki 2014).

U. Dąmbska-Prokop (2000: 58) jako główne przyczyny powstawania błędów tłumaczeniowych podaje: brak wiedzy ogólnej, kompetencji językowych, kulturowych oraz pragmatycznych. Problemem może być także brak predyspozycji do wykonywania zawodu. Niewątpliwie potwierdzają tę teorię przypadki tłumaczy wybuchających płaczem na sali sądowej co miało miejsce w marcu 2014 roku podczas procesu południowoafrykańskiego sportowca Oscara Pistoriusa oskarżonego o morderstwo (Por. Zuydam 2014).

D. Karczewska (2002, 2004: 129) w swoich rozważaniach koncentruje się na błędach sensu stricto, którymi są

„wszelkie zmiany w warstwie semantycznej, pragmatycznej i (lub) stylistycznej w tekście tłumaczenia w stosunku do oryginału, które wypaczają jego sens oraz intencje nadawcy komunikatu wyjściowego".

Błędy te dzieli na: btędy w planie wyrażania oraz błędy w planie treści. Te pierwsze to przede wszystkim niewłaściwa forma tekstu docelowego oraz niewłaściwy dobór ekwiwalentów. Natomiast te drugie dotyczą poprawności przekazania treści komunikatu wyjściowego. Jako najczęstsze przyczyny powstawania błędów podaje ona ograniczoną znajomość języka źródłowego i docelowego, niewystarczającą wiedzę ogólną (np. kulturową, polityczną) i specjalistyczną, nieznajomość technik przekładu oraz zasad wyszukiwania ekwiwalentów.

Z kolei Z. Kozłowska (2002: 138), poza błędami logicznymi, redakcyjnotechnicznymi i drukarskimi, wyróżnia:

1) błędy językowe, widoczne bez porównywania z tekstem źródłowym, oraz

2) błędy tłumaczeniowe (błędy tłumaczeniowe sensu stricto), czyli takie, które są wykrywalne dopiero $\mathrm{w}$ wyniku porównania $\mathrm{z}$ tekstem źródłowym.

Klasyfikacja K. Hejwowskiego (2004) została opracowana w wyniku badań przeprowadzonych na grupie studentów, co niewątpliwie pomogło badaczowi na 
dość precyzyjne ustalenie przyczyn powstania konkretnych błędów (możliwość omówienia pracy tłumaczeniowej z autorem przekładu i wyciągnięcie wniosków z analizy). Hejwowski (2004: 158nn) wyróżnia:

1) błędy interpretacji (wynikające $z$ niezrozumienia tekstu),

2) błędy tłumaczenia powierzchniowego (wynikające $z$ niedostatecznej analizy tekstu źródłowego i braku umiejętności wyszukiwania ekwiwalentów translacyjnych),

3) błędy realizacji (wynikające $z$ braku kompetencji w zakresie języka ojczystego i braku umiejętności oceny wiedzy odbiorcy),

4) błędy metatranslacyjne (wynikające $z$ braku kompetencji tłumaczeniowych).

Badacz zwraca też uwagę na ocenę jakości przekładu i konieczność zastosowania zarówno kryteriów ilościowych jak i jakościowych, gdyż nie każdy błąd pociąga za sobą brzemienne skutki. Biorąc to pod uwag wyróżnia błędy: kardynalne, przeciętne, minimalne czy też dyskusyjne.

R. Lewicki (2000: 138) postuluje by teoretycy przekładu koncentrowali się na przyczynach powstawania i skutkach błędów. Założenie to jest niewątpliwie słuszne, jednak należy sobie też zdawać sprawę z tego, że w sytuacjach oceny przekładu wykonanego na zlecenie często nie mamy niestety kontaktu z tłumaczem, nie znamy jego tożsamości, wykształcenia, itp. i nie zawsze jest możliwe dokonanie precyzyjnej analizy przyczyn powstałych błędów. Można jedynie spekulować na ten temat w oparciu o pewne przesłanki, np. nadmierna liczba błędów literowych sugeruje brak znajomości technik przekładu, a błędy terminologiczne i frazeologiczne braki w zakresie dziedziny jakiej dotyczył tłumaczony tekst.

Ł. Biel (2012: 105) w swojej recenzji dwóch opracowań dla kandydatów na tłumaczy przysięgłych powołuje się na tzw. błąd krytyczny. Pozwolę sobie zacytować tu autorkę, która omawiając kryteria oceny egzaminu dla kandydatów na tłumaczy przysięgłych szczególnie uczula na konsekwencje popełnienia takich błędów wskazując na rozwiązania brytyjskie:

Biorąc pod uwagę specyfikę tłumaczeń poświadczonych, zastanawia niska waga kryterium zgodności treści przekazanej w tłumaczeniu $\mathrm{z}$ treścią oryginału. Kryterium ma identyczną wagę jak poprawność językowa czy zastosowanie rejestru funkcjonalnego, chociaż w praktyce nawet jeden błąd w przekazie informacyjnym, np. zgubienie „not” czy cyfry 0 w kwocie wynagrodzenia, może wywołać katastrofalne skutki i całkowicie zdyskwalifikować tłumaczenie. W brytyjskich testach dla kandydatów na Public Service Interpreters wprowadzono interesującą kategorię błędu krytycznego (ang. fatal error ${ }^{2}$ ) — błędu na tyle poważnego, że skutkuje niezaliczeniem całego testu. Z pewnością takie kryterium wyczula na zmiany znaczenia i szkoda, że polski ustawodawca nie zastosował podobnego rozwiązania. (Biel 2012: 104-105).

\footnotetext{
${ }^{2}$ http://www.iol.org.uk/qualifications/DPSI/FATAL\%20ERRORS\%20FOR\%20WEB.pdf
} 
O błędach krytycznych pisze także J. Dybiec-Gajer (2013) oraz A.D. Kubacki (2014). Prace zbiorowe pod redakcją A. Kopczyńskiego i U. ZaliwskiejOkrutnej (2002) oraz A. Kopczyńskiego i M. Kizeweter (2009) stanowią próbę zmierzenia się z problemem błędów i jakości przekładu, jednakże nie poszerzają istotnie rozważań teoretycznych przedstawionych powyżej. M. Guławska (2005) z kolei koncentruje się na kategorii błędów nazywanych językowymi, które rzadko prowadzą do tzw. błędu krytycznego, choć jak zauważa Kubacki (2012, 2014) nawet błędy literowe w określonych elementach tekstu (np. imionach czy nazwiskach) mogą być brzemienne w skutkach.

Podsumowując, stosunkowo mało miejsca poświęcono błędom dyskwalifikującym tłumaczenie, w dużej mierze skupiając się na wszelkich możliwych usterkach jakie można napotkać w przekładach. Należy zatem stwierdzić, że ta stosunkowo nowa kategoria błędów, jaką jest błąd krytyczny, przez Hejwowskiego (2004) nazywany kardynalnym, powinna być uwzględniana szczególnie w kształceniu tłumaczy tekstów specjalistycznych np. prawniczych czy medycznych, gdyż od jakości przekładu może zależeć czyjeś zdrowie a nawet życie, co ilustrują poniższe przykłady.

\section{Błędy krytyczne i ich źródło}

W dalszej części pracy zostaną przedstawione błędy krytyczne, które okazały się brzemienne w skutki. Zostaną one pogrupowane zgodnie z klasyfikacją Hejwowskiego (2004) na:

1) błędy metatranslacyjne,

2) błędy interpretacji,

3) błędy tłumaczenia powierzchniowego oraz

4) błędy realizacji.

\subsection{Błędy metatranslacyjne}

Błędy metatranslacyjne (Hejwowski 2004) bardzo często prowadzą do zaburzenia efektywności komunikacji interlingwalnej. Są one przede wszystkim wynikiem pominięcia etapu przekładu. Bardzo często pojawiają się u adeptów zawodu, w tym samouków, którzy nie znają zasad wykonywania przekładu i zatrzymują się na etapie tłumaczenia roboczego, będąc tego nieświadomym. Błędy te powstają też w wyniku presji czasu, która uniemożliwia tłumaczowi zachowanie etapów przekładu i zmusza go do pomięcia jednego z nich.

Etapy przekładu można podzielić na pozwalające na eliminację błędów przez tłumacza oraz pozwalające na eliminację błędów przez inną osobę (wery- 
fikatora odpowiedzialnego za usterki merytoryczne i korektora odpowiedzialnego za usterki językowe). Proces przekładu powinien się rozpocząć od ustalenia czy tłumacz jest kompetentny by przetłumaczyć dany tekst. W przypadku tłumaczenia pisemnego polega to na przeczytaniu fragmentu lub całego tekstu w celu ustalenia stopnia jego trudności. W przypadku tłumaczenia ustnego na zapoznaniu się z tematyką tekstów ustnych, które mają być tłumaczone. Tłumacz w teorii i praktyce powinien przyjąć tłumaczenie tylko jeżeli jest w stanie zrozumieć tekst źródłowy. W pozostałych przypadkach powinien odmówić wykonania tłumaczenia. Należy tutaj zaznaczyć, że panujący stereotypowy pogląd mówi, że jeżeli zna się język obcy (w domyśle ukończyło się studia filologiczne), to umie się tłumaczyć. Niestety nie jest to prawdą, gdyż przekład nie polega na automatycznym i bezmyślnym zamienieniu ciągów wyrazów w jednym języku na ciąg wyrazów w innym języku. Gdyby tak było komputerowe translatory już dawno zastąpiły by tłumaczy-ludzi.

Następny etap, który często jest połączony czasowo z wykonywaniem roboczej wersji tłumaczenia, to poszukiwania ekwiwalentnej terminologii i kolokacji. Po wykonaniu roboczej wersji tłumaczenia zasadniczo przed tłumaczem jeszcze dwa dość czasochłonne etapy, a mianowicie dokonanie porównania tekstu źródłowego z wyprodukowanym tłumaczeniem roboczym oraz korekta. Porównanie tekstu źródłowego z docelowym to mozolna praca polegająca na przeczytaniu obu tekstów zdanie po zdaniu w celu ustalenia czy żadna informacja nie została opuszczona, zmieniona, dodana, źle zrozumiana, itd. Jest to najistotniejszy etap przekładu gdyż pozwala na eliminację najpoważniejszych usterek $\mathrm{w}$ tekście docelowym. Problemy związane $\mathrm{z}$ opuszczeniem tego etapu przekładu opisano w artykule opublikowanym 10 stycznia 2005 roku w Gazecie Wyborczej pod znamiennym tytułem: Nie czytać po polsku (str. 2). W tekście tym wytknięto tłumaczom rozporządzeń i dyrektyw unijnych liczne błędy tłumaczeniowe np. użycie w tekście docelowym terminów 'psychicznie' zamiast 'fizycznie', 'import' zamiast 'eksport', czy błędy w elementach istotnych tekstu takich jak dane liczbowe np. ' $15 \%$ ' zamiast ' $1,5 \%$ ', itp. Wszystkie z tych błędów można było bez problemu wyeliminować na etapie porównania tekstu źródłowego $\mathrm{z}$ docelowym.

Ostatni etap, który powinien zostać wykonany przez tłumacza to przeczytanie tekstu docelowego w celu usunięcia ewentualnych usterek językowych, których jeszcze do tej pory nie wykryto. Obejmują one zazwyczaj tak zwane błędy drukarskie w postaci podwójnych kropek czy przecinków, błędy interpunkcyjne, ortograficzna, gramatyczne, stylistyczne. Rzadko są to błędy krytyczne i z tego względu nie będą tutaj bardziej szczegółowo omawiane, jednak informacji na ich temat można szukać w publikacjach dotyczących jakości przekładów na potrzeby Unii Europejskiej (Matulewska i Nowak 2006, 2007, Nowak 2006). 
W idealnej sytuacji translacyjnej jakość przekładu pisemnego powinna być także zapewniona przez udział $\mathrm{w}$ procesie korektora i weryfikatora (por. Tabakowska 1999, 2009), a w przypadku tłumaczenia ustnego przez udział dwóch tłumaczy. Niestety bardzo rzadko jest to praktykowane, głównie ze względu na koszty. Jednakże, zwłaszcza w przypadku przekładu sądowego z cała pewnością pozwoliłby to na wyeliminowanie sytuacji, w których osoba nie posiadająca kwalifikacji językowych w zakresie języka obcego zwodzi uczestników postępowania nieświadomych nieprawidłowości w tłumaczeniu, czego przykładem jest niewątpliwie sprawa z Kanady (źródła internetowe: Kaytie 2013) z 2011 roku o udzielenie azylu pani Neheid.

Pani Samirah Mohamed Neheid, uchodźca z Kenii, wystąpiła wraz z córką o azyl. Po jej przesłuchaniu uznano, że jej zeznania są mało wiarygodne, udzielone odpowiedzi wymijające, a czasami nawet niespójne, czy wręcz sprzeczne. W konsekwencji wydano decyzję o deportacji pani Neheid i jej córki do Kenii. Na szczęście licencjonowani tłumacze ustni języka swahili później wykazali, iż pierwsze tłumaczenie było obarczone licznymi błędami i postanowiono powtórzyć procedurę rozpatrywania wniosku o azyl przez kanadyjski Urząd do spraw Imigracji i Uchodźców (Immigration and Refugee Board, dalej IRB). Co więcej okazało się, że wcześniej w innej sprawie ze względu na zarzut braku kompetencji usunięto tego samego tłumacza ustnego, który tłumaczył zeznania pani Neheid, i zastąpiono go innym. IRB nie podało przyczyny dla której w dalszym ciągu korzysta z usług niekompetentnego tłumacza. Poniżej znajduje się fragment przesłuchania pani Neheid.

Fragment 1: Pani. Neheid zeznała, że jej syn chodził na wiece polityczne i wywieszał plakaty zawierające opozycyjne treści.

Tłumaczenie: "Sometimes he came home with postage." [Czasami przychodził do domu z opłatą pocztową]

Fragment 2: Pani Neheid wyraziła opinię, że tłumacz sobie niezbyt dobrze radzi.

Tłumaczenie: "I want to know, to understanding very well, what he asks this guy." [Chcę wiedzieć, zrozumieć dobrze o co on pyta tego faceta]

Fragment 3: Pani Neheid oświadczyła, że nie ma pewności co do odpowiedzi.

Tłumaczenie: "I was not thinking." [Nie myślałam wtedy]

Fragment 4: Pani Neheid zeznała, że była stronniczką, ale nie członkiem partii politycznej.

Tłumaczenie: "I'm not a member but I was a fanner." [Nie jestem członkiem, ale byłam podżegaczem] 
Fragment 5: Pani Neheid zeznała, że policja wypytywała ją o syna.

Tłumaczenie: "They just asked my son.” [Przepytali/Zapytali tylko mojego syna]

(tłumaczenie na polski A.M.)

Grabau (1996) również zwraca uwagę na ten istotny problem komunikacji interlingwalnej na sali sądowej. Przywołuje on przykład wykorzystywany przez profesora Piatta, który ilustruje dlaczego na sali sądowej powinno być obecnych dwóch tłumaczy.

1. Adwokat (pyta po angielsku): „What is your name?” [Jak się nazywasz?]

2. Tłumacz (w obcym języku do świadka): „What did you eat for breakfast?” [Co jadłeś na śniadanie?]

3. Świadek (w obcym języku): „Ham and eggs.” [Jajka na szynce.]

4. Tłumacz (po angielsku): „My name is John Doe.” [Nazywam się Jan Kowalski.]

(tłumaczenie na polski A.M.)

Z przykładu tego jasno widać, że jeżeli jedyną osobą rozumiejącą obcokrajowca na sali sądowej jest tłumacz, to tylko on wie, czy popełniono błąd. Co więcej, wie to tylko wtedy, gdy sam jest świadomy tego, że go popełnił. Jeżeli natomiast wydaje mu się, że dobrze zrozumiał komunikat, choć tak wcale nie było, szanse na rzetelny proces są znikome. A w niektórych przypadkach nawet gdy dwóch tłumaczy jest obecnych na sali sądowej trudno jest ustalić, który z nich tłumaczył prawidłowo. Taka sytuacja zaszła w USA w 2011 r. podczas procesu Jose Luisa Mendeza w Fort Smith w stanie Arkansas [Mendez v. State, 2011 Ark. 536, Dec. 15, 2011], który został skazany na 60 lat więzienia za gwałt, usiłowanie zabójstwa, włamanie i napaść. Wyrok skazujący został częściowo wydany w związku z zeznaniem samego Mendeza złożonym w języku hiszpańskim, w którym przyznał się on do popełnienia czynów, o które został oskarżony. Zarówno obrona jak i oskarżenie przygotowały własne tłumaczenia tego zeznania. Okazały się one sprzeczne. Podczas przesłuchania zapytano Mendeza czy złapał swoja dziewczynę za szyję. W tłumaczeniu oskarżenia odnajdujemy odpowiedź: „Yo lo hice” [ang. "I did that.”, pol. „Zrobiłem to.”], natomiast w tlumaczeniu obrony „No lo hice” [ang. "I didn't do that.”, pol. „Nie zrobiłem tego."]. Późniejsze badanie tej sprawy wykazało, że tłumacz obrony był certyfikowany przez Stan Arkansas, podczas gdy pracujący dla oskarżenia podchodził do egzaminu certyfikującego lecz go oblał. Ze względu na to, że nie

\footnotetext{
${ }^{3}$ John Doe to zwyczajowo imię i nazwisko nadawane osobie, której tożsamość nie jest znana.
} 
udało się ustalić, który tłumacz dokonał prawidłowego przekładu słów Mendeza, trzeba było przeprowadzić nowy proces sądowy (źródła internetowe: Julia 2012, Kevin 2012, Estill 2012).

\subsection{Błędy interpretacji}

Hejwowski (2004) do błędów interpretacji zalicza usterki wynikające z niezrozumienia tekstu. Bardzo często są to zaburzenia wynikające z nieznajomości idiomatyki języka źródłowego, określonego wariantu języka lub dialektu jakim posługuje się nadawca komunikatu.

Jednym źle przetłumaczonym słowem można zabić człowieka lub pozbawić go wszystkiego co dla niego ważne. V. Benmaman (2000)podaje przykład błędu tłumaczeniowego wykrytego dopiero na etapie apelacji. Kubańczyk, początkowo występujący w charakterze świadka, został oskarżony o handel narkotykami gdyż odpowiadając na prośbę o udzielenie pożyczki wypowiedział następujące słowa ,¡Hombre, ni tengo diez kilos!”. W dialekcie, którym się posługiwał oznaczało to „Człowieku, nie mam nawet grosza przy duszy” [,,[m]an, I don't even have ten cents.”]. Niestety tłumacz sądowy przetłumaczył wypowiedź dosłownie na ,[m]an, I don't even have ten kilos.” [„,Człowieku, nie mam nawet 10 kilogramów"] co zinterpretowano jako przyznanie się do posiadania dużych ilości narkotyków. Wyrok ze względu na błąd został na szczęście dla oskarżonego uchylony (por. Grabau i Gibbons 1996).

\subsection{Błędy tłumaczenia powierzchniowego}

Błędy tłumaczenia powierzchniowego (Hejwowski 2004) wynikają z niedostatecznej analizy tekstu źródłowego i braku umiejętności wyszukiwania ekwiwalentów translacyjnych. Takie właśnie błędy zostały popełnione przez tłumacza w sprawie z Kaliforni People v. Nguyen (Ewell 1989) w 1989 roku. Wietnamczyk Quang Nguyen, który miał obsesję na punkcie pewnej Wietnamki, włamał się do jej domu i zabił jej męża. Żona ofiary zeznawała w sądzie jako świadek zdarzenia. Tłumacz niestety zmieniał treść zadawanych pytań i udzielanych odpowiedzi opuszczając pewne fragmenty bądź wręcz zmieniając komunikat. Doprowadziło to do obniżenia wiarygodności świadka, powołanego przez prokuratora, który w oczach sędziego i ławy przysięgłych udzielał sprzecznych odpowiedzi na pytania, miotał się w zeznaniach i wprowadzał w błąd oskarżenie, które wielokrotnie musiało zadawać te same pytania by uzyskać jednoznaczną odpowiedź. 
Poniżej znajduje się przykład ilustrujący popełniane błędy tłumaczeniowe (Ewell 1989):

Zastępca prokuratora: "Did you, your husband or anybody to your knowledge keep a gun in the house?" [Czy Pani, Pani mąż lub ktokolwiek o kim Pani wiedziała trzymali broń w domu?']

Tłumacz w jęz. wietnamskim: "Did you or your husband keep a gun in the house?" [Czy Pani lub Pani mąż trzymali broń w domu?"]

Świadek: "No.” [,Nie”]

Zastępca prokuratora pyta jeszcze raz: “Although, didn't your son Long have a BB gun?” [,A czy nie jest prawdę, że Pani syn Long miał broń typu BB”]

Świadek: "Yes.” [,,Tak"]

(tłumaczenie na polski A.M.)

Jak widać z powyższego przykładu tłumacz opuścił frazę ,anybody to your knowledge", co doprowadziło z punktu widzenia odbiorcy przekładu do wysunięcia wniosku, że żona ofiary udziela sprzecznych odpowiedzi (zaprzecza sama sobie). W konsekwencji Nguyen został skazany za manslaughter (zabójstwo w afekcie) a nie murder (zabójstwo kwalifikowane, z premedytacją), czyli uzyskał łagodniejszy wymiar kary, który nie był zagrożony karą śmierci.

W sprawie People v. Truong, 553 N.W .2d 692 (Mich. 1996) doszło do podobnych zaburzeń komunikacji. Truong został uznany winnym zabójstwa z premedytacją i skazany na dożywocie bez możliwości ubiegania się o objęcie amnestią, pomimo zapewnień oskarżonego, że działał w samoobronie. Podczas apelacji ujawniono, że tłumacz dokonywał nadinterpretacji tekstu np.: zamiast „strzeliłem” tłumaczył ,zabiłem”.

\subsection{Błędy realizacji}

Kolejnym istotnym, a rzadko omawianym aspektem przekładu, jest relatywizacja komunikatu do potrzeb odbiorcy. Błędy w tym zakresie Hejwowski (2004) umieszcza w kategorii błędów realizacji, do których zalicza problemy wynikające $\mathrm{z}$ braku kompetencji w zakresie języka ojczystego i braku umiejętności oceny wiedzy odbiorcy. Sztandarowym przykładem błędów krytycznych popełnionych $\mathrm{w}$ zakresie dostosowania przekładu do potrzeb komunikacyjnych i wiedzy odbiorcy na temat systemu prawnego jest sprawa z Melbourne z 1992 r. opisana przez Nagao (2005). Błędy w przekładzie dramatycznie wpłynęły na życie pięciorga Japończyków i Malezyjczyka. Yoshio Katsuno, jego dwaj bracia (Mitsuo i Masaharu), a także Kiichiro Asami i Chika Honda oraz Malezyjczyk Su zostali w 1992 roku skazani w Melbourne za przemyt heroiny. Malezyjczyk Su i Japończyk Yoshio, który był odpowiedzialny za zorganizowanie wycieczki, 
zostali skazani na 25 lat więzienia, później skrócony w wyniku apelacji do lat 10. Pozostałe osoby zostały skazane na 15 lat więzienia.

Przykład z Nagao (2005: 6-7):

\begin{abstract}
„Ma pan prawo skontaktować się z obrońca z urzędu (You have a right to call a Legal Aid). Zdanie to zostało przetłumaczone jako: 'Istnieje organizacja zwana Legal Aid (pomoc prawna), która związana jest z prawem. Czy chce Pan skontaktować się z nią?’ (Termin „Legal Aid” nie jest znany Japończykom). Podejrzani nie wiedzieli wówczas, że Legal Aid oznacza adwokata, który działa jako obrońca z urzędu. Dlatego też nie skorzystali z tej propozycji, sądząc, że być może będą musieli dużo zapłacić za zaangażowanie adwokatów." (tłumaczenie na polski Z. Rybińska)
\end{abstract}

„Ma Pan prawo do złożenia własnoręcznie napisanego oświadczenia. (You have a right to write a handwritten statement). To było właściwe postępowanie prawne, w którym podejrzanemu dano szansę złożenia własnoręcznie napisanego oświadczenia. Ale tłumacz powiedział: „Może Pan napisać to, czego Pan nie powiedział dotychczas.” (You can write anything that you have not mentioned before.). Podejrzany myślał, że wszystko to co powiedział wcześniej zostało przetłumaczone przesłuchującemu i odpowiedział: Nie, powiedziałem wszystko. (No, I have said everything.)." (tłumaczenie na polski Z. Rybińska)

„Kto spakował torbę? (Who packed the bag?) (...) tłumacz zmienił na; „Skąd pochodzą Pana rzeczy osobiste?" (Where did your belongings originally come from?). Wówczas podejrzany złożył wyjaśnienie dotyczące rzeczy w torbie, która przywiózł z Japonii dodając, że torba została skradziona.” (tłumaczenie na polski Z. Rybińska)

Jednym z głównych problemów, które ujawniono około 10 lat później był fakt, że tłumacz dokonywał pominięć, dodania informacji, streszczeń i samowolnych interpretacji. Używał terminów wieloznacznych w języku japońskim np. nimotsu 'bagaż, rzeczy osobiste', lub terminów o innym znaczeniu niż te użyte w języku źródłowym np. to pack 'pakować' przetłumaczono jako serii 'ułożenie, arrangement'. Zdarzały sie też przypadki, że zadawał pytania z własnej inicjatywy (prawdopodobnie z niepohamowanej ciekawości) (Nagao, 2005: 6-7). Jak to wpłynęło na życie 4 niewinnych osób? Spędzili po 10 lat w więzieniu. Chika Honda trzykrotnie podczas odbywania kary targnęła się na własne życie. Kiichiro Asami przeszedł udar. Konieczne było także trzykrotne przeprowadzenie operacji serca.

\title{
5. Zakończenie
}

Mimo że z przytoczonych przykładów widać jasno jak istotny dla życia uczestników postępowania sądowego, biorących udział w komunikacji interlingwalnej za pośrednictwem tłumacza jest jakość wyprodukowanego przez niego 
przekładu, w rzeczywistości bardzo rzadko zdarza się, by sąd uwzględnił zarzut apelacji oparty na braku kompetencji powołanego tłumacza i z tego wynikającej nieefektywnej komunikacji. Jedną z nielicznych spraw, w których ten problem wysunął się na pierwszy plan jest sprawa z USA znana jako State of Illinois $v$ Starling, 1974, 1st District (21 Ill App 3d 217). Na etapie rozpatrywania apelacji sąd uznał, że zeznania jedynego świadka oskarżenia nie były zrozumiałe (,understandable, comprehensible and intelligible”) a zarówno oskarżenia jak i obrona wielokrotnie zwracały uwagę sądowi, że tłumacz nie zapewnia efektywności komunikacji. Protokoły sądowe wykazały także, że tłumacz był upominany przez sędziego za wielokrotne wdawanie się w dyskusje ze świadkiem, które nie były protokołowane. W wyroku apelacyjnym wskazano, że oskarżony został pozbawiony możliwości obrony, gdyż nie mógł się ustosunkować do zeznań jedynego świadka oskarżenia, a sędzia zaniedbał swoich obowiązków gdyż nie powołał innego tłumacza, mimo że w pełni zdawał sobie sprawę z problemów komunikacyjnych. Sąd apelacyjny orzekł wtedy, że:

"The only cure upon discovery of an incompetent interpreter is to appoint another interpreter, one who will translate truly, competently, and effectively, each question and answer with due regard for his or her oath to do so."

[Jedyne co można zrobić, gdy odkryje się niekompetencje tłumacza, to powołanie nowego tłumacza, który będzie tłumaczył rzetelnie, kompetentnie i efektywnie każde pytanie i każdą odpowiedź z odpowiednim poszanowaniem przysięgi, którą składa w tym zakresie.]

(tłumaczenie na polski A.M.)

Przyczynami błędów może być także przemęczenie, problemy osobiste czy choroba. W 2009 roku tłumacz szwedzko-południowo kurdyjski stracił prawo wykonywania zawodu nadane mu w 2004 roku przez szwedzki Kammarkollegiet. Ttumaczyt on $w$ czasie procesu o zabójstwo $w$ Norrköping. Kammarkollegiet otrzymał doniesienie o nieprawidłowościach w tłumaczeniu podczas procesu. Analiza taśm z przesłuchań wykazała, że popełnił kilka błędów tłumaczeniowych, pomijał pewne fragmenty tekstu, błędnie tłumaczył idiomy, a nawet dodawał własne komentarze. Tłumacz, który w 2004 roku otrzymał licencję na wykonywanie zawodu tłumacza ustnego i pisemnego, szkolił tłumaczy ustnych, publikował przekłady i był autorem słownika prawniczego, wyjaśnił, że problemy osobiste spowodowały, że nie mógł się właściwie skoncentrować na pracy (źródła internetowe: Ullman 2010, także artykuł z 16 sierpnia 2006 r. - brak danych autora).

Podsumowując, każdy absolwent filologii, który potencjalnie może zostać tłumaczem powinien być świadomy odpowiedzialności jaka na nim ciąży. $\mathrm{Na}$ każdych studiach filologicznych i tłumaczeniowych powinno się uczulać słuchaczy na konsekwencje nieefektywnej komunikacji interlingwalnej. 


\section{Bibliografia}

Bańczerowski J., Pogonowski J, i T. Zgółka. 1982. Wstęp do językoznawstwa. Poznań: Wydawnictwo Naukowe UAM.

Benmaman, V. 2000. "Interpreter issues on appeal". PROTEUS IX (4). 1-9.

Biel, Ł. 2011. „Jakość przekładu prawnego i prawniczego w świetle normy europejskiej PN-EN 15038 oraz hipotezy uniwersaliów translatorycznych”. Rocznik Przekładoznawczy 6. 13-28.

Biel, Ł. 2012. „Egzamin na tłumacza przysięgłego - zbiory tekstów egzaminacyjnych”. Comparative Legilinguistics 9. 103-108.

Dąmbska-Prokop, U. (red.). 2000. Mała encyklopedia przekładoznawstwa. Częstochowa: Educator.

Dybiec-Gajer, J. 2013. Zmierzyć przektad? Z metodologii oceniania w dydaktyce przektadu pisemnego. Kraków: Universitas.

Dzierżanowska, H. 1990. Przekład tekstów nieliterackich. Warszawa: Wydawnictwo Naukowe PWN.

Ewell, M. 1989. "What jury heard was not what was said". San Jose Mercury News, Dec. 17, 1989, 16A.

Grabau, Ch.M. i L.J. Gibbons. 1996. "Protecting the rights of linguistic minorities: challenges to court interpretation". 30 New England. Law Review 227. 265-266.

Grucza, F. 1978. „Ogólne zagadnienia lapsologii”. W: Grucza, F. (red.). Z problematyki błędów obcojęzycznych. Warszawa: Wydawnictwa Szkolne i Pedagogiczne.

Guławska, M. 2005. „Stylistyka i kultura języka polskiego dla tłumaczy”. Neofilolog 26. 70-77.

Hejwowski, K. 2004. Kognitywno-komunikacyjna teoria przekładu. Warszawa: Wydawnictwo Naukowe PWN.

Hejwowski, K. 2009. Klasyfikacja błędów tłumaczeniowych - teoria i praktyka. W: Kopczyński, A. i M. Kizeweter. (red.). Jakość i ocena ttumaczenia, Warszawa: Wydawnictwo Szkoły Wyższej Psychologii Społecznej „Academia”. 141-161.

Karczewska, D. 2002. „O błędach w tłumaczeniu”. W: Kopczyński, A. i U. Zaliwska-Okrutna. (red.). Język rodzimy a język obcy, komunikacja, przektad, dydaktyka. Warszawa: Wydawnictwa Uniwersytetu Warszawskiego. 129-135.

Kielar, B.Z. 1996. „Na manowcach tłumaczenia tekstu prawnego: prawdopodobieństwo wywołania szoku kulturowego". W: Grucza, F. i K. Chomicz-Jung. (red). Problemy komunikacji interkulturowej. Jedna Europa - wiele języków i wiele kultur. Warszawa: Wydawnictwo Uniwersytetu Warszawskiego. 135-141.

Kielar, B.Z. i E. Lewandowska. 1999. ,Towards better communication: cultural and terminological aspects of Polish translations of English texts relating to copyright law". W: Tomaszczyk, J. (red.). Aspects of legal language and legal translation. Łódź: Wydawnictwo Uniwersytetu Łódzkiego. 171-182.

Kierzkowska, D. 2002. Ttumaczenie prawnicze. Warszawa: Wydawnictwo TEPIS.

Kopczyński, A. i M. Kizeweter. (red.). 2009. Jakość i ocena ttumaczenia. Warszawa: Wydawnictwo Szkoły Wyższej Psychologii Społecznej „Academia”.

Kopczyński, A. i U. Zaliwska-Okrutna. (red.). 2002. Język rodzimy a język obcy, komunikacja, przekład, dydaktyka. Warszawa: Wydawnictwa Uniwersytetu Warszawskiego.

Kozłowska, Z. 2002. „O błędach językowych w tekstach polskich przekładów”. W: Kopczyński, A. i U. Zaliwska-Okrutna. (red.). Język rodzimy a język obcy, komunikacja, przekład, dydaktyka, Warszawa: Wydawnictwa Uniwersytetu Warszawskiego. 137-147.

Kubacki, A.D. 2008. „Odpowiedzialność zawodowa tłumaczy przysięgłych”. Język, Komunikacja, Informacja 3. 149-161.

Kubacki, A.D. 2011. „Analiza błędów w tłumaczeniu na język polski dokumentu spadkowego 'Erbschein'”. Lingua Legis 20. 66-75. 
Kubacki, A.D. 2012. Ttumaczenie poświadczone. Status, ksztatcenie, warsztat i odpowiedzialność ttumacza przysięgłego. Warszawa: Wolters Kluwer Business.

Kubacki, A.D. 2014. „Błąd krytyczny w tłumaczeniach poświadczonych” [w druku].

Lewicki, R. 2000. Obcość w odbiorze przektadu. Lublin: Wydawnictwo UMCS.

Matulewska, A. i P. Nowak. 2006. „Translation errors and mistakes in Polish language versions of EU legal texts". Język, Komunikacja, Informacja 1.31-40.

Matulewska, A. i P. Nowak. 2007. „Problems in translation of EU legal texts into Polish”. W: Kierzkowska, D. (red.). Court interpreting and legal translation in the enlarged Europe 2006. Warszawa: Wydawnictwo TRANSLEGIS. 123-133.

Nagao, H. 2005. „Sprawa z Melbourne: niewłaściwe tłumaczenie przyczyną oskarżenia o niepopełnione przestępstwa". Przeł. Rybińska, Z. Lingua Legis 13. 3-7.

„Nie czytać po polsku“. Gazeta Wyborcza 10 stycznia 2005.

Nord, Ch. 1999. „Transparenz der Korrektur“. W: Snell-Hornby, M. et al. (red.). Handbuch Translation. Tübingen: Stauffenburg Verlag. 384-387.

Nowak, P. 2006. „Analiza błędów w przekładzie unijnych aktów normatywnych na przykładzie Council Regulation (EC) no 1346/2000 of 29 May 2000 on Insolvency Proceedings“. Investigationes Linguisticae XIII. 171-195.

Pantoga, H. 1999. "Injustice in any language: the need for improved standards governing courtroom interpretation in Wisconsin". Marquette Law Review 82: 601. 601-664.

Pisarska, A. i T. Tomaszkiewicz. 1996. Wspótczesne tendencje przekładoznawcze. Poznań: Wydawnictwo Naukowe UAM.

Porzycki, M. 2004. „Lawina bełkotliwych przekładów”. Rzeczpospolita 26 marca 2004 (wersja elektroniczna).

Solová, R. 2013. Norma i praktyka w przekładzie tekstów skonwencjonalizowanych. Na materiale ttumaczeń poświadczonych z języka polskiego na język francuski $i$ z języka francuskiego na język polski. Wrocław: Oficyna Wydawnicza ATUT.

Szczygłowska, M. 2011. „Błąd tłumaczeniowy z punktu widzenia antropocentrycznej teorii (rzeczywistych) języków ludzkich”. W: Grucza, S., Marchwiński, A. i M. Płużyczka (red.). Translatoryka. Koncepcje - modele - analizy. Warszawa: IKL@.400-406.

Tabakowska, E. 1999. O przektadzie na przykładzie. Kraków: Wydawnictwo Znak.

Tabakowska, E. 2009. Ttumacząc się z ttumaczenia. Kraków: Wydawnictwo Znak.

Taylor, L. i L.R. Dazda. 2002. „W wyniku błędnego tłumaczenia sąd amerykański zarządził nowy proces. Złe tłumaczenie powodem uchylenia wyroku”. Przeł. Gołębiowska, E. Biuletyn TEPIS 47. 24-26.

Uhlig, D. 2005. „Nie czytać po polsku”. Gazeta Wyborcza 10 styczeń 2005. 2.

Wyrok Sądu Apelacyjnego z dnia 8 czerwca 2010 r., sygn. akt III APo 5/10 (niepublikowany).

Zabrocki, L. 1963. Wspólnoty komunikatywne w genezie i rozwoju języka niemieckiego. Część I. Prehistoria języka niemieckiego. Wrocław/Warszawa/Kraków: Zakład Narodowy imienia Ossolińskich Wydawnictwo Polskiej Akademii Nauk.

\section{Źródła internetowe}

16 sierpnia 2006. (Brak nazwiska autora) "Accuracy is essential in legal and court interpreting”. Legal Language Services. http://www.legallanguage.com/legal-articles/legal-court-interpreting/

Estill, J.M. 9 marca 2012. "Is a certified interpreter necessary?" Blog: National Association of Judiciary Interpreters and Translators. http://najit.org/blog/?p=151 
Humphreys, A. 18 lipca 2011. “Translator error sinks woman's refugee hearing”. National Post. http://news.nationalpost.com/2011/07/18/translator-error-sinks-womans-refugee-hearing/

Institute of Linguistics: http://www.iol.org.uk/qualifications/dpsi/fatal\%20errors\%20for\%20 web.pdf

Julia. 16 lutego 2012. "Court interpreting mistakes can lead to mistrials". Legal Language Services. http://www.legallanguage.com/legal-articles/court-interpreter-mistrial/

Kaytie. 3 maja 2013. "Canadian court interpreter botches Swahili". Legal Language Services. http://www.legallanguage.com/legal-articles/canadian-court-interpreter-botches-swahili/

Kevin. 9 marca 2012 "Interpreter Error? Not This Time?" Blog: National Association of Judiciary Interpreters and Translators. http://najit.org/blog/?p=151

"Legal language Arkansas translation error by court interpreter leads to new trial". Legal Language Services. http://www.legallanguage.com/legal-articles/court-interpreter-arkansas/

Ullman, T. 2010. "Interpreter loses license after translation mistakes during trial". Stockholm News. 21 lipca 2010. http://www.stockholmnews.com/more.aspx?NID=5679

Zuydam, L. van. 2014. "Oscar trial: interpreter under fire". IOL News. March 4 2014. http://www. iol.co.za/news/crime-courts/oscar-trial-interpreter-under-fire-1.1655689\#.VCugUvl_uCo

\section{Precedensy sądowe}

Mendez v. State [Calf. 2011] Ark. 536, Dec. 15, 2011.

Negrón v. People [New York 1970].

People v. Truong [Mich. 1996] 553 N.W .2d 692. 